\title{
Hydrodynamic Circulation under Tide Conditions at the Gulf of Evoikos, Greece
}

\author{
Evangelos Tsirogiannis, Panagiotis Angelidis, Nikolaos Kotsovinos \\ Division of Hydraulics, Department of Civil Engineering, Democritus University of Thrace, Kimmeria Campus, Xanthi, Greece \\ Email: pangelid@civil.duth.gr
}

How to cite this paper: Tsirogiannis, E. Angelidis, P. and Kotsovinos, N. (2019) Hydrodynamic Circulation under Tide Conditions at the Gulf of Evoikos, Greece. Computational Water, Energy, and Environmental Engineering, 8, 57-78.

https://doi.org/10.4236/cweee.2019.83004

Received: May 26, 2019

Accepted: June 24, 2019

Published: June 27, 2019

Copyright $\odot 2019$ by author(s) and Scientific Research Publishing Inc. This work is licensed under the Creative Commons Attribution International License (CC BY 4.0).

http://creativecommons.org/licenses/by/4.0/

\begin{abstract}
Hydrodynamic circulation in the marine environment, characterized by the effects of the intense tide conditions, the atmospheric loading, and the bathymetry, constitutes a complex phenomenon. The present paper deals with the numerical simulation of the hydrodynamic circulation of the Gulf of Evoikos, which is characterized by the existence of a strong tide. The Estuarine and Lake COmputer Model three-dimensional hydrodynamic model has been used, which, besides the tide, takes into consideration the atmospheric forces acting on the surface of the study area, such as the solar radiation, the atmospheric pressure, the relative humidity, the rainfall height, the air temperature and the wind speed and direction. The physical and hydrodynamic characteristics of the water circulation under tide conditions are examined such as the salinity, the water temperature, the density stratification, the flow velocities, the tracer concentration, etc. These characteristics are absolutely critical for the diffusion and dispersion of passive pollutants, the water flow renewal, and the general environmental situation.
\end{abstract}

\section{Keywords}

Hydrodynamic Circulation, Tide, Gulf of Evoikos, Greece

\section{Introduction}

Coastal systems are usually affected by many interacting processes such as waves, tides and river inflows. The effects of tide are of especial importance and researchers have been looking for modeling this effect. So, much effort has been made to model this phenomenon [1] [2] [3] [4] [5]. In coastal waters, hydrodynamic processes greatly influence the transport of contaminants, nutrients, living biomasses and suspended particles. Transport times to leave a certain area of interest through its outlets to the sea are generally used as the first approach of 
transport to evaluate the health of coastal ecosystems. The simulation of momentum, heat and salt vertical turbulent exchange is very important for coastal systems circulation models.

The tidal currents in the Gulf of Evoikos (Greece) are possibly amongst the earliest historically studied tidal phenomena. Eratosthenes, Pitheas, Posidonios [6], as well as Stravon and Senekas [7] are only some of the scholars that appear to have studied this phenomenon in antiquity. The Gulf of Evoikos has been the subject of a remarkable number of studies from the early 20th century [6] [7] [8] [9] [10]. Aiginitis [7] conducted an in-depth review of the bibliography and measurements with regard to the tide in the Gulf of Evoikos. Sterneck [9] simulated the propagation of the tidal waves along the axis of the northern and southern Gulf of Evoikos, assuming that the Euripus Straits are closed and managed to describe the main characteristics of the tide. The first hydrodynamic model for the studied area was constructed by Livieratos [6], while Tsimplis [11] applied two models, a low resolution one for the propagation of tidal waves in the northern and southern Gulf of Evoikos and a high resolution one, focused on the Gulf's Straits.

Despite the fact that the tidal phenomenon of the Gulf of Evoikos has been studied since antiquity, there are still, today, no systematic measurements nor any significant number of related studies available. Tidal stations, as well as satellite altimeter data, were used [12] to systematically monitor the change in sea level on the southern Europe coastlines. Overall, 17 tidal stations were installed on the shores of the Mediterranean Sea and the Atlantic Ocean, though none were installed within the borders of the Gulf of Evoikos. The tidal dynamics taking effect in the interconnected system between the Mediterranean Sea, the Sea of Marmara, the Black Sea and the Azov Sea were investigated [13], and the numerical results yielded a description of the main tide characteristics of the system. The contribution of the tidal currents [14] was examined in respect to the resuspension, the erosion, and the deposition of suspended sediments in the Marine area of Avlida, located within the set boundaries of the study area for this paper.

The changes in the seasonal sea level extremes were estimated [15] based on and extending a previous work [16]. Hourly sea level data from 46 tide gauges were used to investigate the variability of sea level extremes in the Mediterranean Sea and the Atlantic European coasts. The tidal hydraulics and the tidal exchange of two lagoons in Western Greece (located in close proximity to the study area) were numerically simulated [17]. It was found that, despite the fact that the two lagoons have similar dimensions and present very similar tidal forcing, the flushing rates differ greatly, due to the intricacies of the tidal hydrodynamics. The Euripus tidal stream was also studied [18] in order to evaluate the tidal flow's ability to produce hydrokinetic renewable energy.

The ELCOM (Estuarine and Lake COmputer Model) model, which was developed in the Center of Water Research in the Western Australia University, is a widely used and robust numerical model, for the hydrodynamic simulation of 
lakes, estuaries and enclosed seas. This model has been used successfully in many relevant research studies around the world, including, but not limited to, research examining the North Aegean Sea [19] [20], and the Adriatic Sea [21], both located in great proximity to the study area of this work, as well as the Persian Gulf [22], a study which also included a simulation of the tide. However, the ELCOM model was selected in this work for an additional reason. The model links seamlessly with the CAEDYM model (Computational Aquatic Ecosystem Dynamics Model). The combination of the two codes provides three-dimensional transport and interactions of flow physics, biology, and chemistry for inland and coastal waters.

This study deals with the computational simulation of the hydrodynamic circulation in the Gulf of Evoikos region. We used the ELCOM three-dimensional hydrodynamic model, which incorporates the intense tide effect characterizing the study area, and climatic factors such as the total solar radiation, the atmospheric pressure, the relative humidity, the rainfall, the air temperature, the wind speed, and direction. To our knowledge, there is currently no other relevant published research examining this issue, regarding the area considered. The aim of this paper is to investigate the natural and hydrodynamic characteristics of this tidal flow, including, among others, the salinity, the water temperature, the density stratification, the water circulation, the flow rates, etc. Those characteristics play a critical role in the vertical mixing of the marine masses and, consequently, the mixing of their physicochemical parameters, such as nutrients and oxygen, as well as the water renewal in the Gulf of Evoikos. The tide is a strong mechanism for movement and mixing of the coastal waters. But the question is if this mechanism is strong enough to prevent density stratification, which greatly affects the dilution of the wastewater disposed in the study area. The study's ultimate objective concerns the investigation of the diffusion and dispersion of passive pollutants in this area under the influence of the above-mentioned parameters. The subject area consists of two semi-closed basins, which are connected to each other through a narrow and shallow waterway. The present work will give answers to what is happening with a pollutant or tracer entering into one semi-closed basin, if this tracer spreads into the other, in what concentration and after how much time. There are no answers for these questions until today and the objective of this paper is to clarify the hydrodynamic circulation and respond to these issues, which are very important for the high tourist and populated region near around the study area.

\section{Materials and Methods}

\subsection{Study Area}

The study area (Figure 1) consists of the northern Gulf of Evoikos with a total area of $1060 \mathrm{~km}^{2}$ and the southern Gulf of Evoikos with an area of $900 \mathrm{~km}^{2}$. These two Gulfs are connected to each other through the Euripus Strait, a narrow and shallow canal measuring $40 \mathrm{~m} \times 40 \mathrm{~m} \times 10 \mathrm{~m}$. The study area's predominant feature is the occurrence of strong tides. 


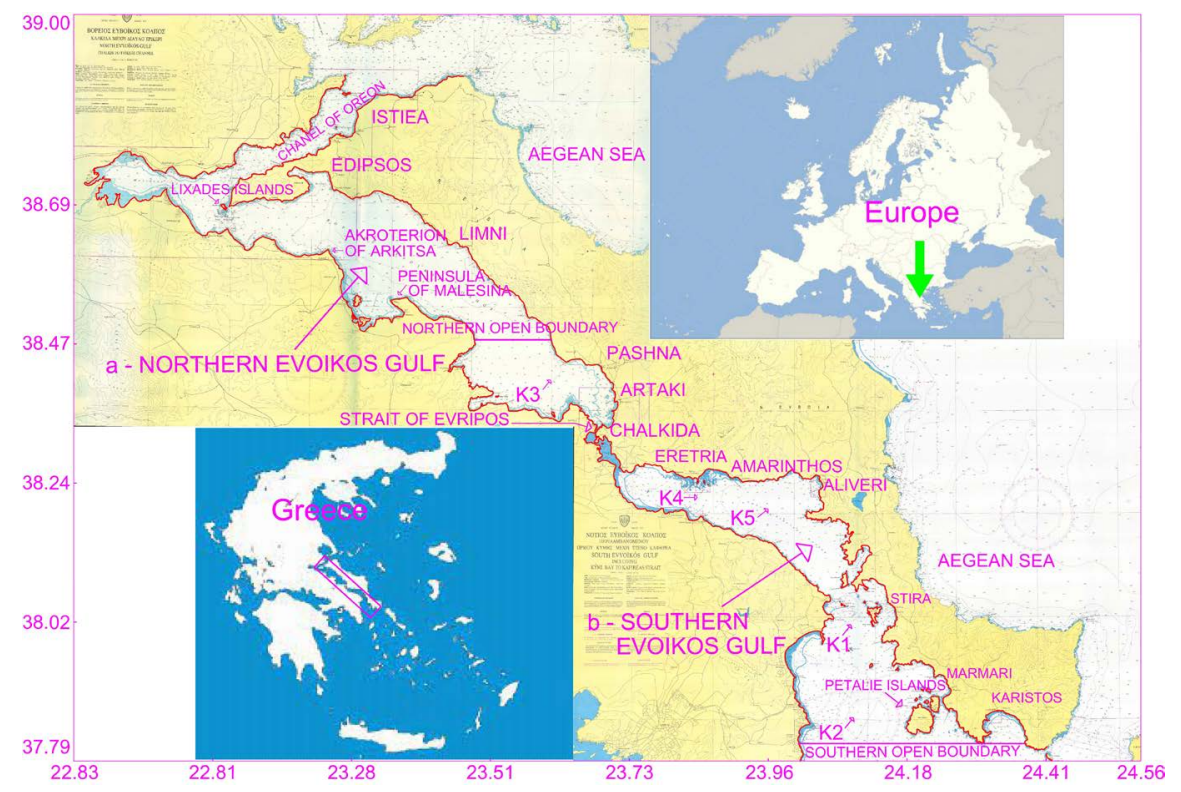

Figure 1. Map of the northern and the southern Gulf of Evoikos.

The northern Gulf of Evoikos constitutes a longitudinal basin of northwest-southeast general direction, divided into three sections: the western, the central and the southeast section (Figure 1). The western section, located between the Lichades Islands and the Cape of Arkitsa, appears smooth, with an average depth of about $80-100 \mathrm{~m}$. The central section with a maximum depth of $450 \mathrm{~m}$ constitutes the deepest part of the Gulf and extends from the Cape of Arkitsa all the way to the Malesina Peninsula. It is characterized by a steep north slope, as opposed to the shallow, smooth south slopes, behind which develops a large continental shelf develops, with the south slope being characterized by the presence of numerous submarine canyons. The southeastern part appears smooth, while its borders extend all the way from the Malesina Peninsula to the Euripus Strait. This section exhibits a shorter bathymetry of $60-130 \mathrm{~m}$ in its upper-northern part, with its greatest depth being mapped in the region around Evia, and culminates in a depth of $10 \mathrm{~m}$ at the Strait area.

The broader basin of the southern Gulf of Evoikos is a semi-closed basin, connected to the Aegean Sea through the Straits between the Islands of Evia and Kea. The main Gulf of the southern Evoikos is a small, elongated sea basin with a northwest-southeast general direction. The basin bed layer of the southern Gulf of Evoikos consists of Holocene sediments that might extend to a thickness of $14 \mathrm{~m}$, while the sea bottom is dominated by mud except for the shallow coastal areas, where the sand may reach up to $50 \%$ of its overall consistency [23]. The area where the tidal phenomenon occurs is contained between the narrow Oreoi Strait at the northern end and the Petalie Island at the southern end of Evoikos.

\subsection{Brief Description of the ELCOM Model}

The water circulation in the Gulf of Evoikos was simulated using the ELCOM three-dimensional, finite difference hydrodynamic model, which is suitable for 
the simulation of lakes and enclosed seas. It is used to predict the spatial and temporal variation of the water temperature and salinity. The model is based on the unsteady Reynolds-averaged Navier-Stokes (RANS) equations for incompressible flow and on scalar transport equations. The Boussinesq approximation is used and the non-hydrostatic pressure terms are omitted. The free surface level change is expressed by an evolution equation developed by a vertical integration of the continuity equation applied to the Reynolds-averaged kinematic boundary condition.

The Reynolds equations are solved and the closing of the turbulent flow equation system in the horizontal direction is carried out using a turbulent viscosity coefficient, while, for the vertical direction, a vertical energy layer mixing model is utilized. The ELCOM model offers the ability to include the influence of the tide. Density is calculated as a function of salinity and temperature. At the same time, the model also considers the meteorological load, i.e. the effect that the wind, the solar radiation, the rainfall, and other meteorological parameters have on the water surface layer [24] [25]. The surface exchanges of heating due to short wave radiation penetration into the water and the fluxes at the surface due to evaporation, sensible heat and long wave radiation are also simulated.

In a staged approach, the ELCOM model takes into consideration, in each time step, the following procedures: 1) introduction of surface heating/ cooling in the surface layer, 2) mixing of scalar concentrations and momentum using a mixed-layer model, 3) introduction of wind energy as a momentum source in the wind-mixed layer, 4) solution of the free-surface evolution and velocity field, 5) horizontal diffusion of momentum, 6) advection of scalars, and 7) horizontal diffusion of scalars.

\subsection{Model Setup}

The Gulf of Evoikos region chosen for the numerical simulation of this research is depicted in Figure 2. It is bounded to the west and east by Central Continental Greece-Attica and Evia respectively, as well as by the northern and southern Aegean Sea. For the purposes of this research, we constructed a rectangular computational grid of variable dimensions, incorporating rectangular computational discretization cells ranging in dimensions between $40 \mathrm{~m} \times 100 \mathrm{~m}$ and 400 $\mathrm{m} \times 400 \mathrm{~m}$. The gradual change of the computational cell dimensions was necessary due to the $40 \mathrm{~m}$ width limit of the Euripus Strait on the one hand, and in an attempt to avoid creating an excessive number of cells on the other hand in the case of solely incorporating dimensionally stable cells of $40 \mathrm{~m} \times 40 \mathrm{~m}$, which would have made it impossible to execute the computational code. Based on this limitation, the computational simulation included the entire southern Gulf of Evoikos and (1/3) of the northern Gulf of Evoikos. The northern and southern boundaries of the simulated area are illustrated in Figure 1.

A total of 20 layers were set in the vertical direction. The first 8 layers, extending just below the surface, were variable in thickness ranging from $2.5 \mathrm{~m}$ to 


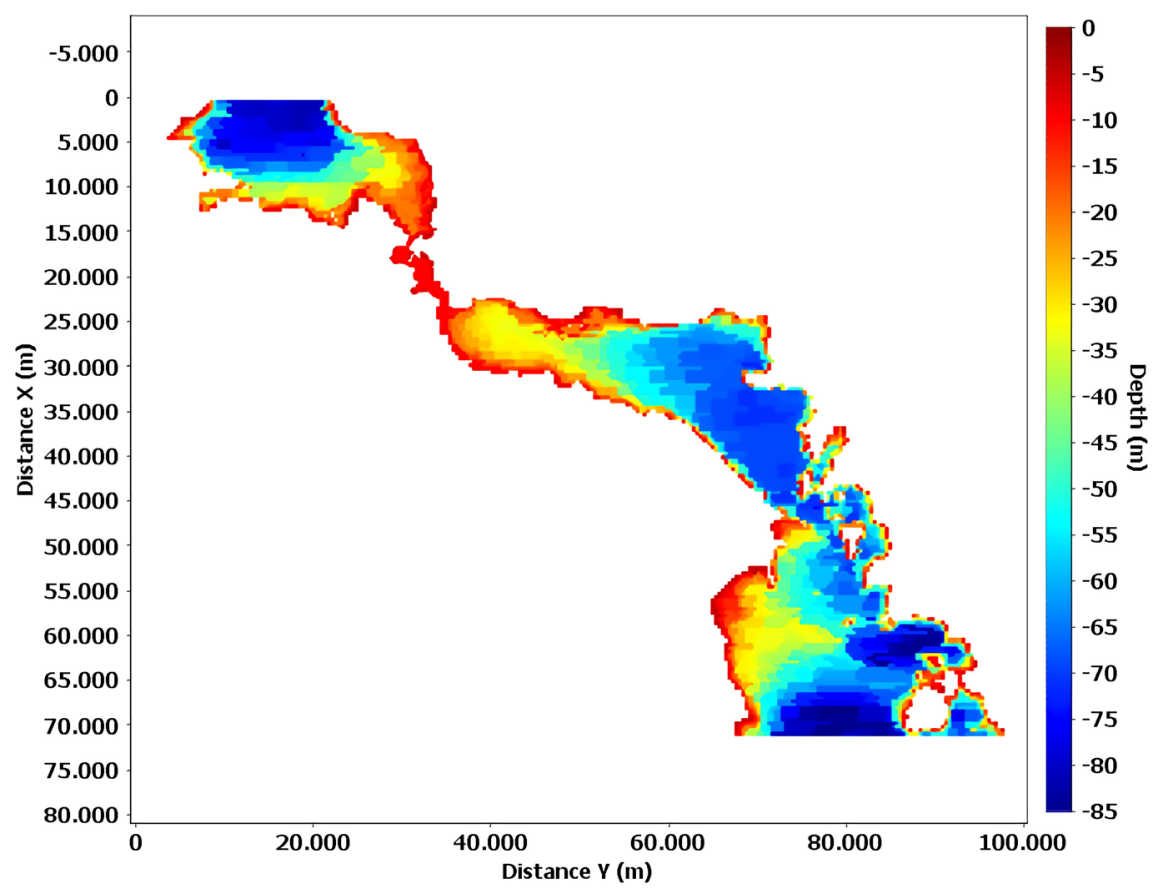

Figure 2. Bathymetric map of the simulation area of the Gulf of Evoikos.

$5.0 \mathrm{~m}$, presenting a progressive increase in width size, while the remaining 13 deeper located layers reaching down to the bottom of the sea exhibited a constant thickness of $5.0 \mathrm{~m}$. This vertical discretization along with the choice of the densest possible vertical computational grid, were chosen in order to: 1) simulate as accurately as possible the hydrodynamic circulation of the Euripus Strait, presenting a depth of $10 \mathrm{~m}$, which is absolutely critical for the communication between the northern and southern Gulf of Evoikos, 2) better illustrate the results concerning the shallow coastal areas of particular interest, and 3) achieve the highest possible accuracy regarding the vertical distribution of the velocities (in particular tidal), the density stratification and the tracer concentrations, based on depth. The maximum simulation depth reached $-86.0 \mathrm{~m}$. The computational grid consisted of 225,351 active water cells.

A turbulent benthic boundary condition was used at the bottom applying an invariant friction coefficient. In the northern and southern boundaries of the computational domain, an "open" boundary condition was applied, which passively allowed the water inflow to, or outflow from each cell, according to the corresponding flow needs. Based on observations and measurements reported in the literature [7] [11], marginal conditions of sea level variability were imposed on the northern and southern boundaries for the purposes of the tidal simulation, according to Figure 3.

While reviewing the literature, we were unable to find any temperature and salinity measurements regarding the northern and southern borders of the Gulf of Evoikos with the open Aegean Sea, in order to utilize them in the present study as marginal conditions. The only data we were able to retrieve concern water 


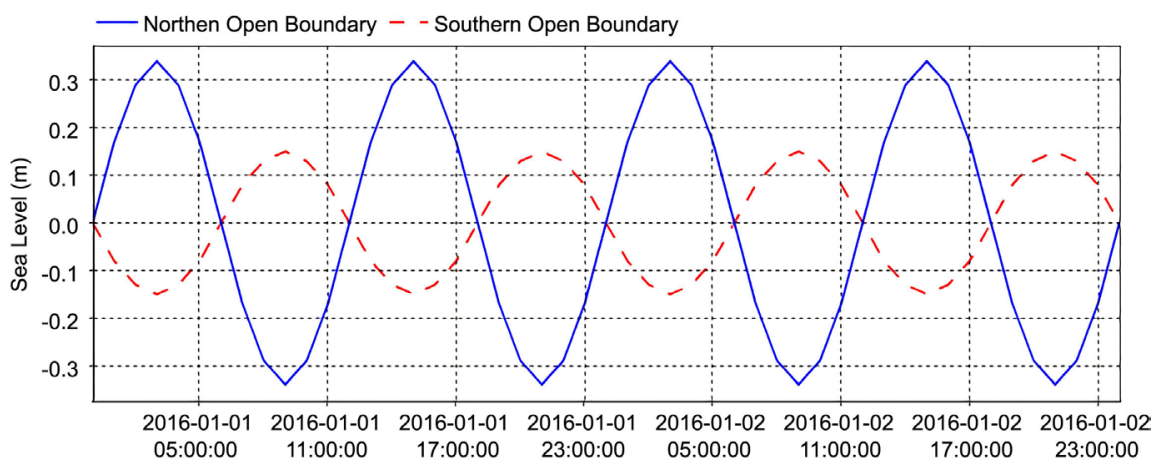

Figure 3. Sea level change due to the tide for a time period of 48 hours, at the northern and southern "open" marginal conditions of the computational simulation using the ELCOM model.

temperature and salinity forecast information for these locations based on the COPERNICUS marine environmental monitoring service. The COPERNICUS system (http://marine.copernicus.eu), based on both satellite and on-the-spot monitoring networks, provides analysis and daily forecasts, thus enabling the observation, understanding, and prediction of marine parameters. In the present study, we used the Mediterranean Forecasting System (MFS), which is a subsystem of the COPERNICUS, and which has been providing analytical and short-term forecast data of the main natural parameters of the Mediterranean Sea since 2000 [26] [27] [28]. The MFS is a coupled hydrodynamic and wave model applied across the Mediterranean Sea with a $1 / 24^{\circ}$ (about $4 \mathrm{~km}$ ) horizontal grid discretion, which also includes 141 distributed vertical water column points. This model considers the Dardanelles Straits closed, including in its function, at the same time, the inflow entering through the Straits. It extends slightly into the Atlantic Ocean to simulate water exchange with the Mediterranean Sea through the Strait of Gibraltar and does not include tidal phenomena.

In the present study and based on the COPERNICUS system data, we calculated the average monthly values, across the length of the water column at the upper and lower boundaries of the computational domain (Figure 4). We, then, applied to the northern and southern open boundary for each month during the simulation period of this study. These values were assumed invariable for all cells as we moved to greater depths and within the aforementioned limits.

The initial conditions of salinity and temperature at the beginning of the simulation were the same for all the cells of the computational domain and equal to $38.88 \mathrm{psu}$ and $18.35^{\circ} \mathrm{C}$, respectively. These numbers represent the average values for the year 2016, as they result based on the COPERNICUS system. The time interval between the loops was equal to $1.0 \mathrm{~min}$. The simulation time period corresponded to one year (2016), which was considered as a representative typical year. Meteorological data were inserted every 10 minutes, regarding the wind speed and direction, the atmospheric pressure, the air temperature, the relative humidity, the rainfall, and the solar radiation. These data (Figure 5) were collected and calculated by meteorological stations of the National Meteorological 


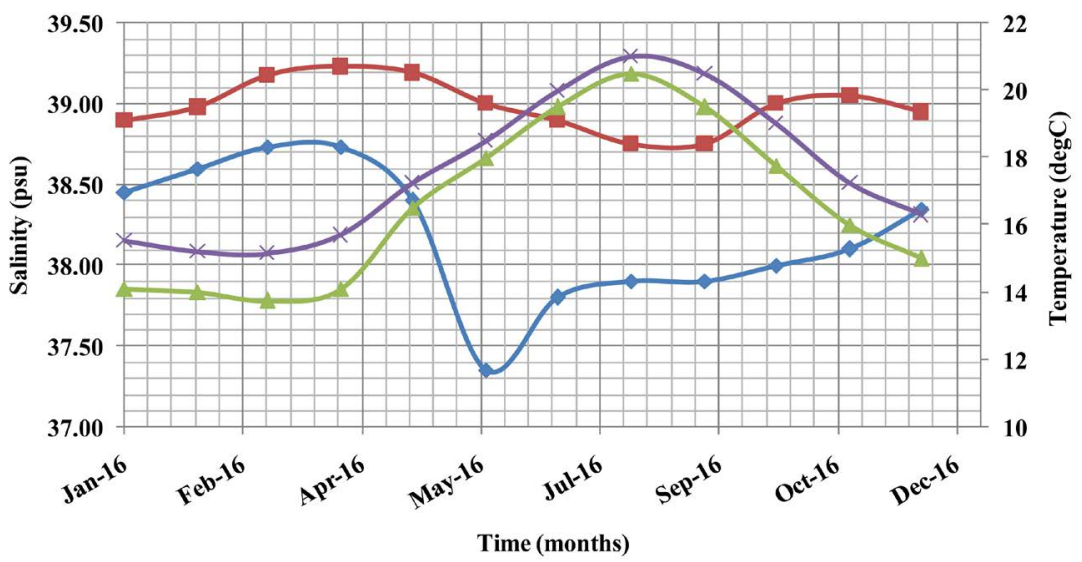

$\multimap$ Salinity in Northern Open Boundary $\quad-$ Salinity in Southern Open Boundary
$\leftarrow$ Temperature in Northern Open Boundary $*$ Temperature in Southern Open Boundary

Figure 4. Average monthly temperature and salinity values in the northern and southern open boundary condition.
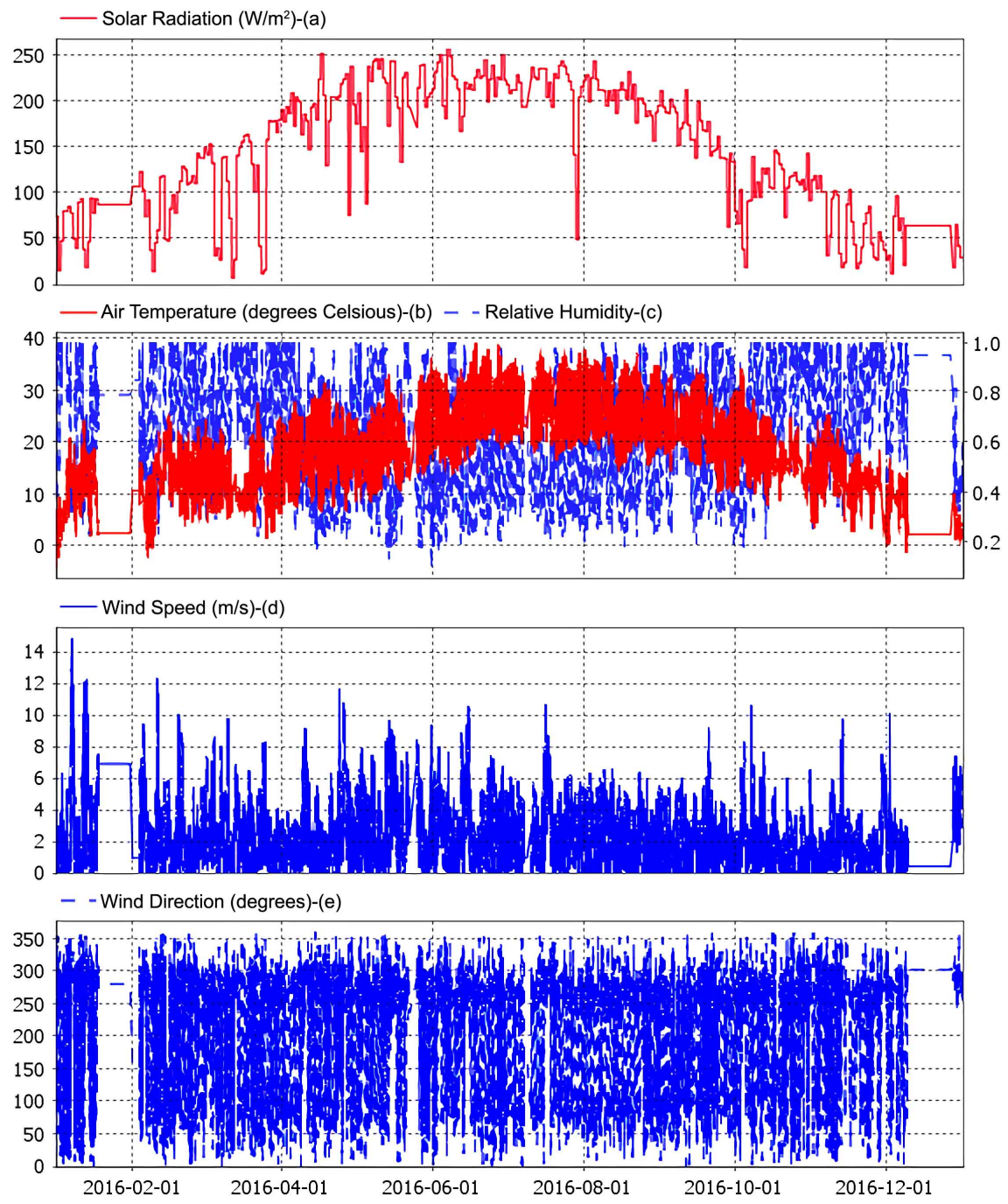

Figure 5. (a) Solar radiation, (b) air temperature and (c) relative humidity, (d) wind speed and (e) direction per 10 minutes for the year 2016 in the study area. 
Service, located in the cities of Lamia and Aliarto, which are adjacent to the study area.

The water movement observed on the open boundary conditions of the North and South Aegean is simulated using two conservative tracers (tracer-north, tracer-south). These two indicators, with a dimensionless concentration within the set limits equal to 1 , aimed at monitoring the origin of the waters in each cell of the computational space and their mixing with the waters of Evoikos, during the evolution of the simulation.

The validity of the results deriving from this paper was assessed by comparing the velocity in the most critical point of the study area, which is the Euripus strait. The maximum water velocity developed in the Euripus Strait, during a half-period ( $\mathrm{T} / 2=6$ hours), is about $2.5 \mathrm{~m} / \mathrm{s}$ [29], while measurements made in the natural field at this point, in 2010, by the Hellenic Centre for Marine Research (HCMR) [30], showed that the maximum speed values greatly approach this value. The above mentioned observations are confirmed by the results of the present study, based on which we were able to identify a maximum speed value, within the Strait limits, of about $2.5 \mathrm{~m} / \mathrm{sec}$, presented at times corresponding to the midpoint of the tidal half-period. Figure 6(a) depicts the flow velocities in the Euripus Strait, both on the surface and at a depth of $5.0 \mathrm{~m}$ from the surface, for a random 24-hour timeframe (14/09/2016), as they derive from the simulation of the present work, using the ELCOM model. Based on Figure 6(a), we conclude that on both the surface and at a depth of $5.0 \mathrm{~m}$, the maximum speed is $2.5 \mathrm{~m} / \mathrm{sec}$, i.e. similar to the value measured in the field. Notably, the speed remains approximately constant across the depth of $10 \mathrm{~m}$ at the Euripus Strait, as
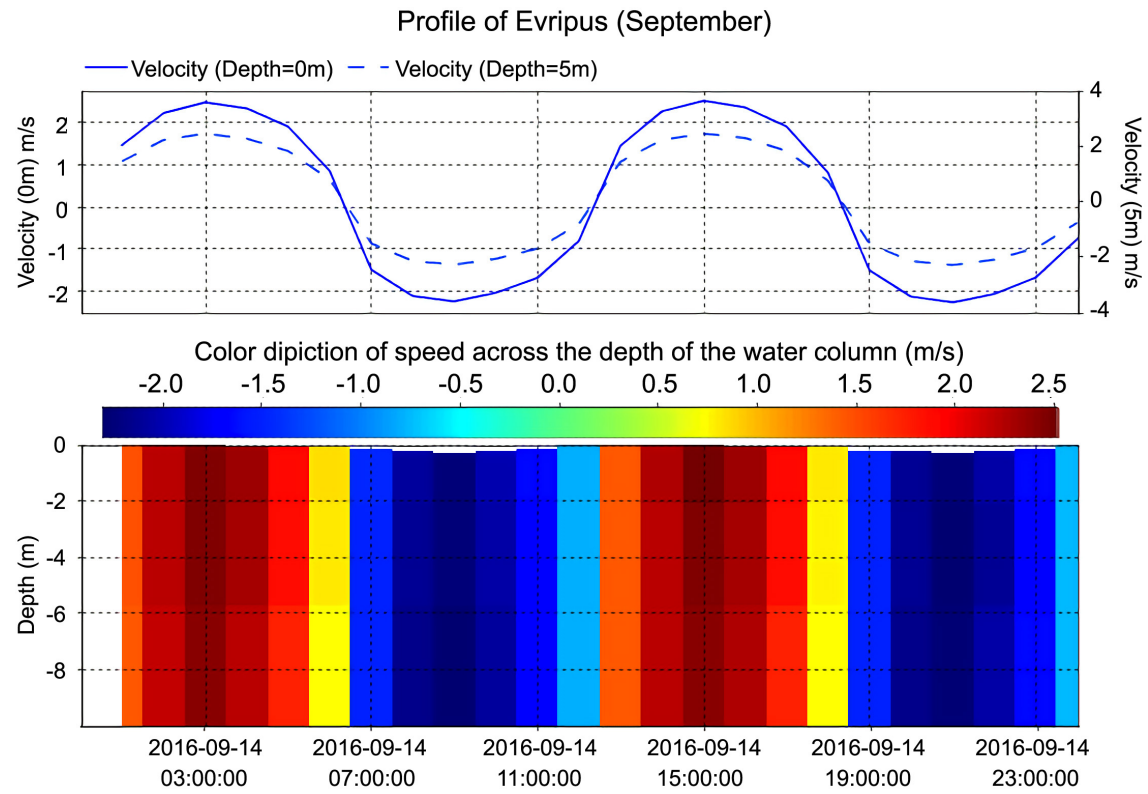

Figure 6. (a) Time variation of the flow velocity in the Euripus Strait, both, on the surface and at a depth of $5.0 \mathrm{~m}$ from the surface, for a random 24-hour (14/9/2016), and (b) color depiction of the velocity values in the Euripus Strait across the depth of the water column, for 24-hours (14/9/2016). 
demonstrated by the color depiction of Figure 6(b), and further confirmed by the HCMR measurements [30]. Therefore, the Euripus Strait operates as an open channel, carrying water quantities from the northern to the southern Gulf of Evoikos and vice versa.

\section{Results and Discussion}

Since there are no systematic field measurements for salinity, temperature, density in the studied region, the results of the present study will be compared with available predictions based on the COPERNICUS model at two points, namely, $\mathrm{K} 1$ and $\mathrm{K} 2$, of the southern Evoikos, the corresponding locations of which are demonstrated in Figure 1. The comparison given at these two points is simply indicative, because the two models ELCOM and COPERNICUS are based on completely different mathematical and numerical approaches, and the tide is simulated only by the ELCOM model.

\subsection{Salinity}

Figures 7(a)-(d) show the evolution of mean salinity values at different depths $(1,20,40,60 \mathrm{~m})$, as they result based on the simulation of the present work (ELCOM) and the COPERNICUS system at point K1. It should be noted that the predictions of the two models are similar. The same observation is also made for the comparison results of the data comparison for point $\mathrm{K} 2$, and for depths of 1 , 30, 50, $70 \mathrm{~m}$ (Figures $7(\mathrm{e})-(\mathrm{h})$ ).

Figure 8 presents a comparison of the vertical distribution of the mean salinity values, as they result based on the simulation of the present work (ELCOM) and as a forecast based on the COPERNICUS system at point K2, for the months of August (Figure 8(a)) and December (Figure 8(b)). As can be clearly observed, the simulation results using both models are very close. Similarly, the results of the two simulations are nearly equivalent for the K1 point as well for the several months examined.

\subsection{Temperature}

Figure 9 demonstrates the time evolution of the mean temperature values, at point $\mathrm{K} 1$, for the surface (depth of $1 \mathrm{~m}$ ) and for a depth of $10 \mathrm{~m}$, based on the simulation of the present work (ELCOM) and the forecast data of the COPERNICUS system. For the entire duration of the simulation period, overall lasting one year, a satisfactory convergence of results between the two models is finally obtained.

Vertical distribution of the mean temperature values at point $\mathrm{K} 1$ is shown in Figure 10(a), Figure 10(b) for the months of May and June, respectively. After comparing the forecast data of this work, using the ELCOM model, to the COPERNICUS system data, we, once again, obtain a satisfactory convergence. The alternating direction of the velocity field, due to the tide, which is simulated only by the ELCOM model, is probably the main reason for the water temperature differences of the two models at depths about $40 \mathrm{~m}$ to $60 \mathrm{~m}$. 


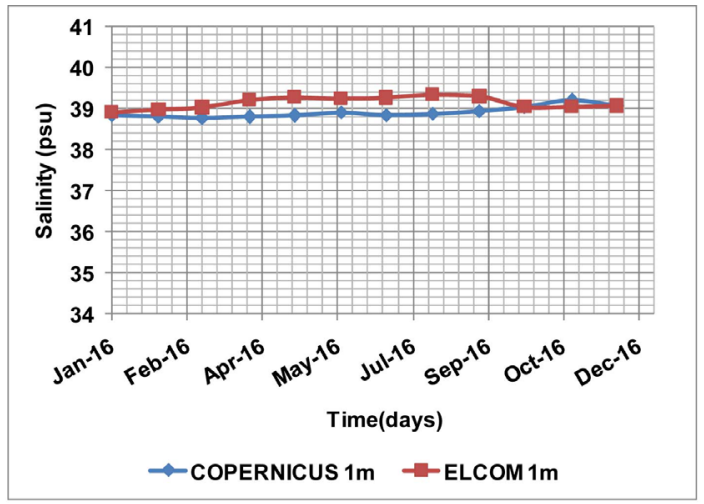

(a)

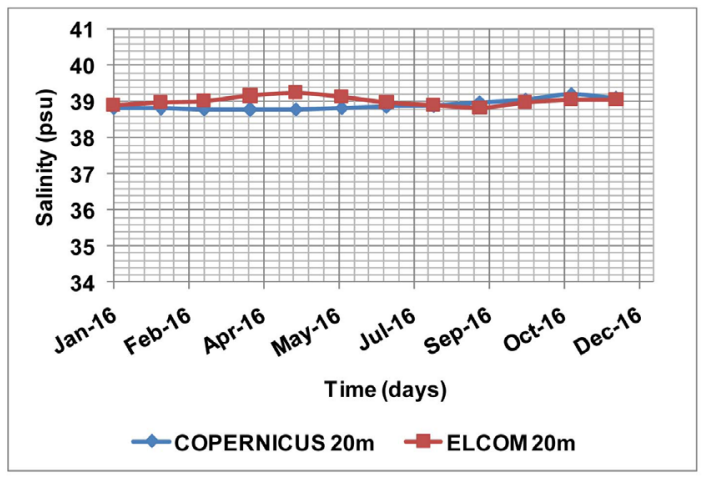

(b)

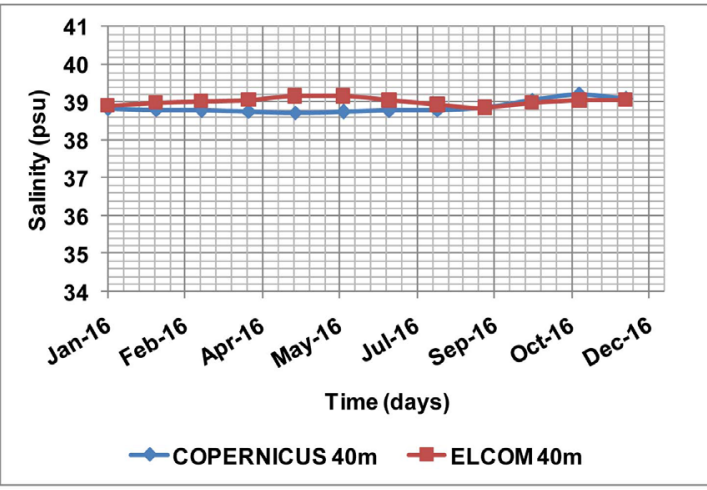

(c)

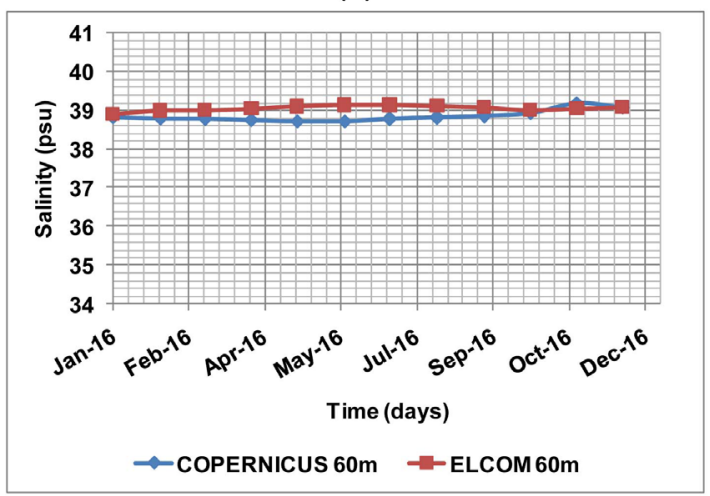

(d)

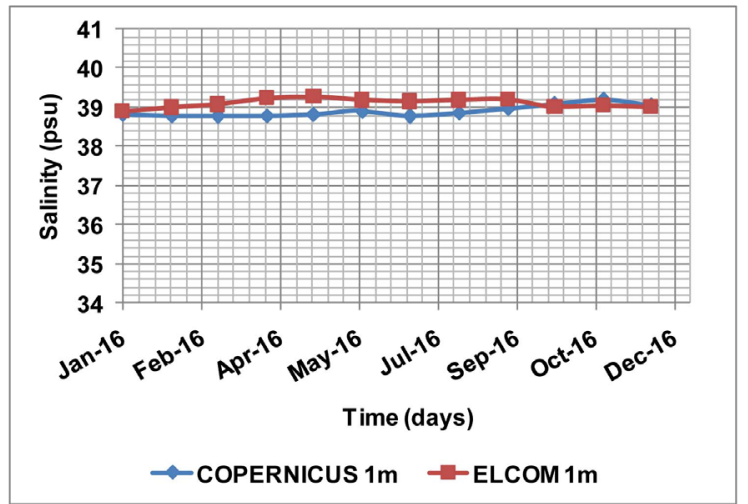

(e)

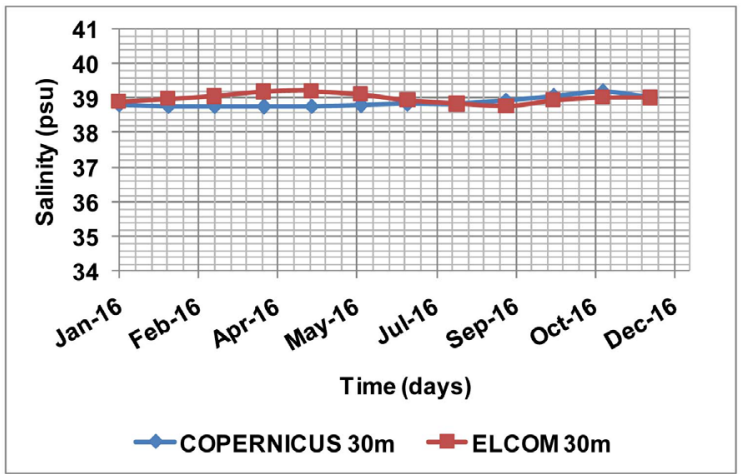

(f)

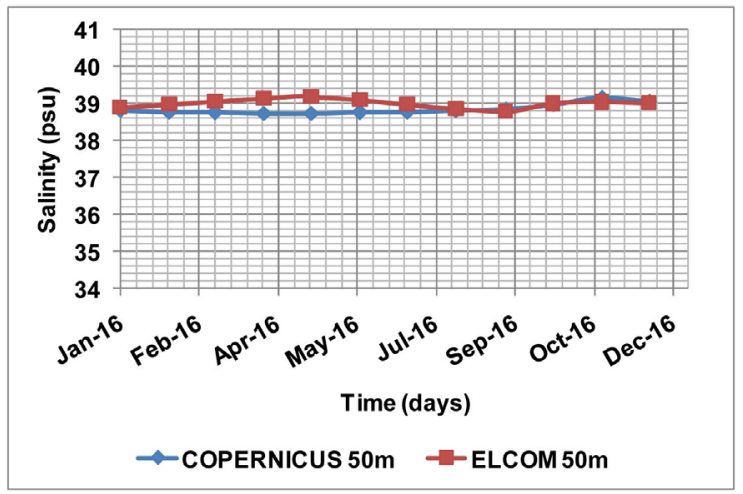

(g)

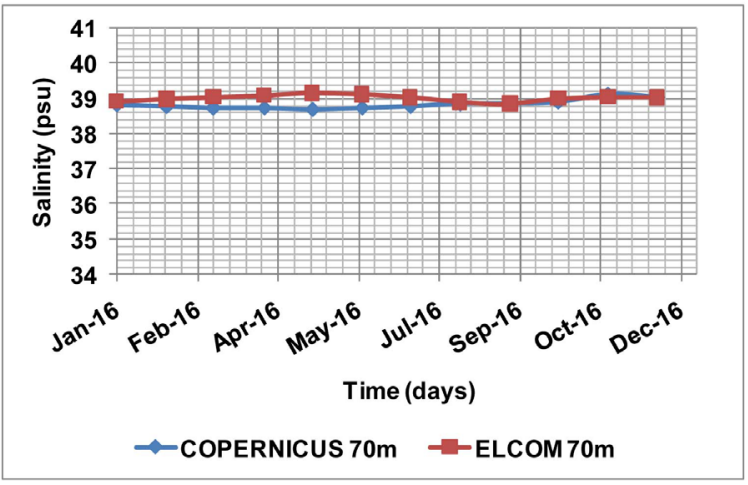

(h)

Figure 7. Comparison of the mean salinity values in a vertical water column for various depths, as results by the simulation of the present work (ELCOM) and the COPERNICUS system at points K1 (a)-(d) and K2 (e)-(h). 


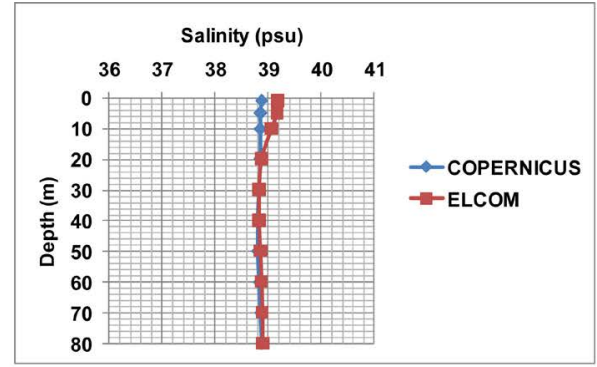

(a)

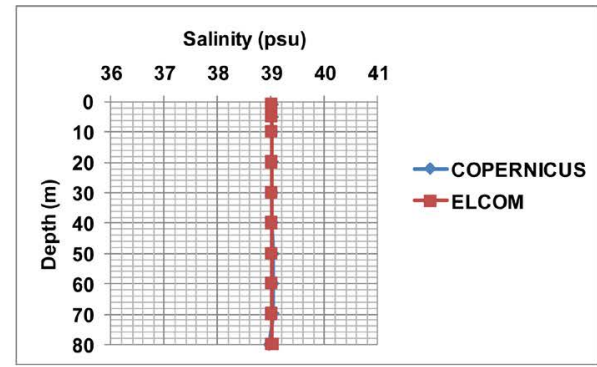

(b)

Figure 8. Comparison of the vertical distribution of the mean salinity values, as they result based on the simulation of the present work (ELCOM) and the COPERNICUS system at point K2, for the months of August (a) and December (b).

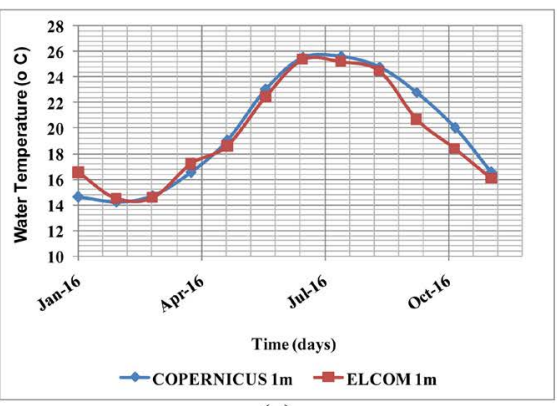

(a)

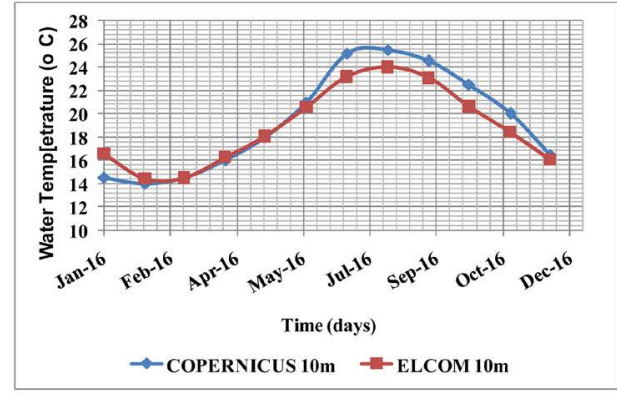

(b)

Figure 9. Time variation of the mean temperature values: (a) at depth of $1 \mathrm{~m}$, and (b) at a depth of $10 \mathrm{~m}$, at point $\mathrm{K} 1$, as they result based on the simulation of the present work (ELCOM) and the COPERNICUS system.

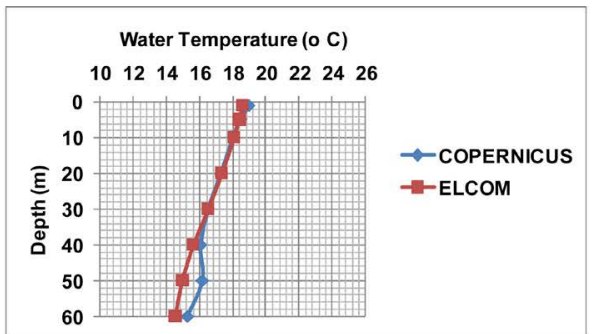

(a)

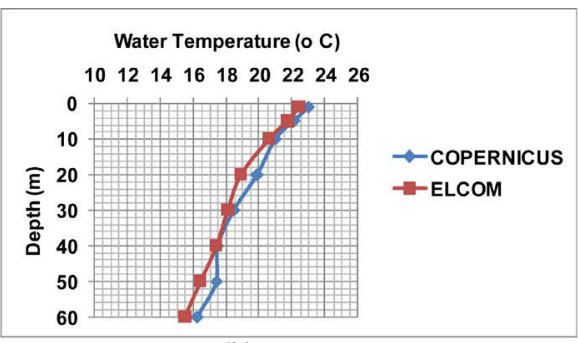

(b)

Figure 10. Comparison of the vertical distribution of the mean temperature values, as they result based on the simulation of this work (ELCOM) and the COPERNICUS system, at point K1, for the months of May (a) and June (b).

\subsection{Velocity}

Figure 11 illustrates the spatial distribution of the surface flow velocity in the Euripus Strait region, on the 3rd hour of 14/09/2016. The flow resembles a river flow (open channel) of a rectangular cross-section, transferring water between the northern and the southern Gulf of Evoikos. An indicative speed vector diagram at a random moment of the simulation, for the southern Gulf of Evoikos, is presented in Figure 12, for visualization and understanding reasons. This surface movement results from the combined effect of the tide, the prevailing meteorological conditions, and the bathymetry. 


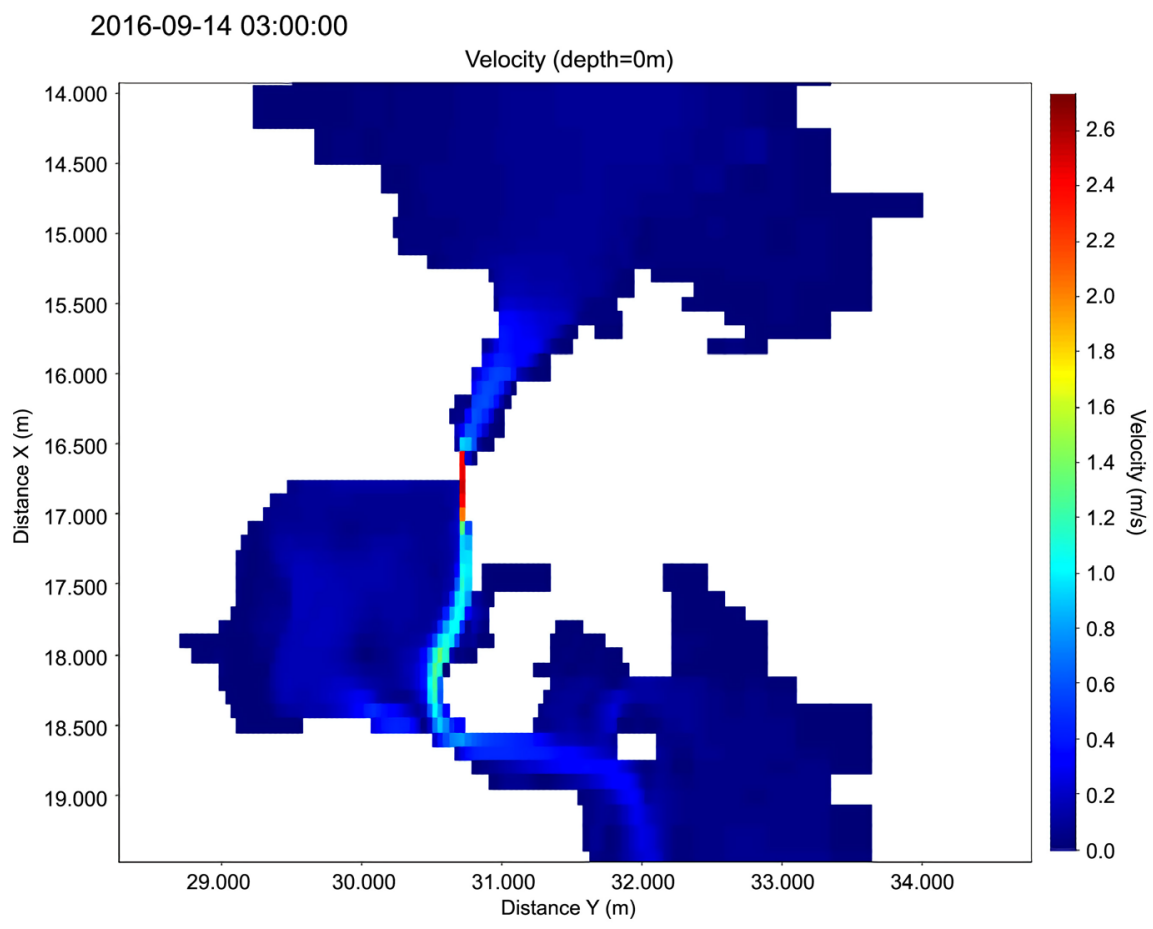

Figure 11. Spatial distribution of the surface flow velocity in the Euripus Strait region at the 3rd hour of 14/9/2016.

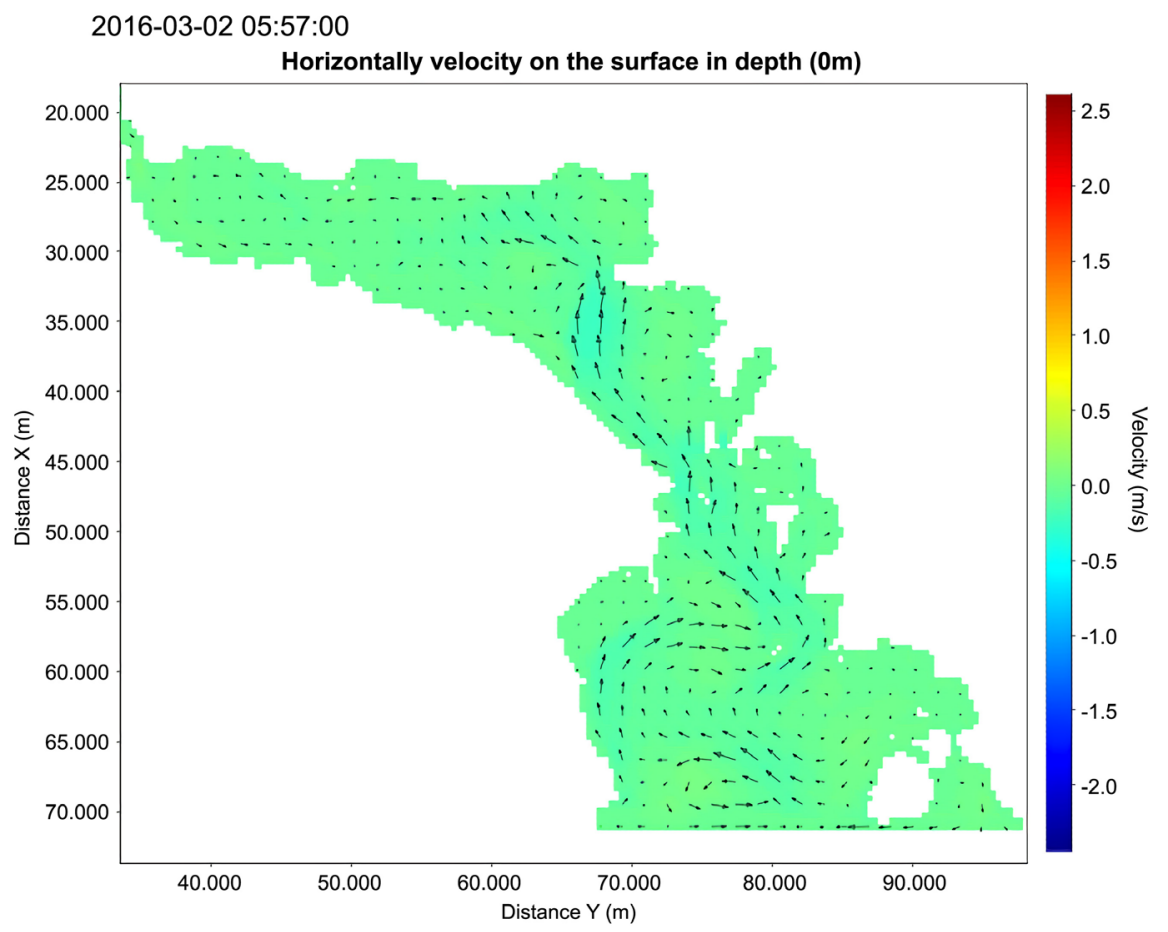

Figure 12. Indicative diagram of the water velocity vectors on the surface, at a random moment of simulation for the southern Gulf of Evoikos.

\subsection{Density}

Figure 13 shows the distribution of the density $\sigma$ values on the surface layer of 


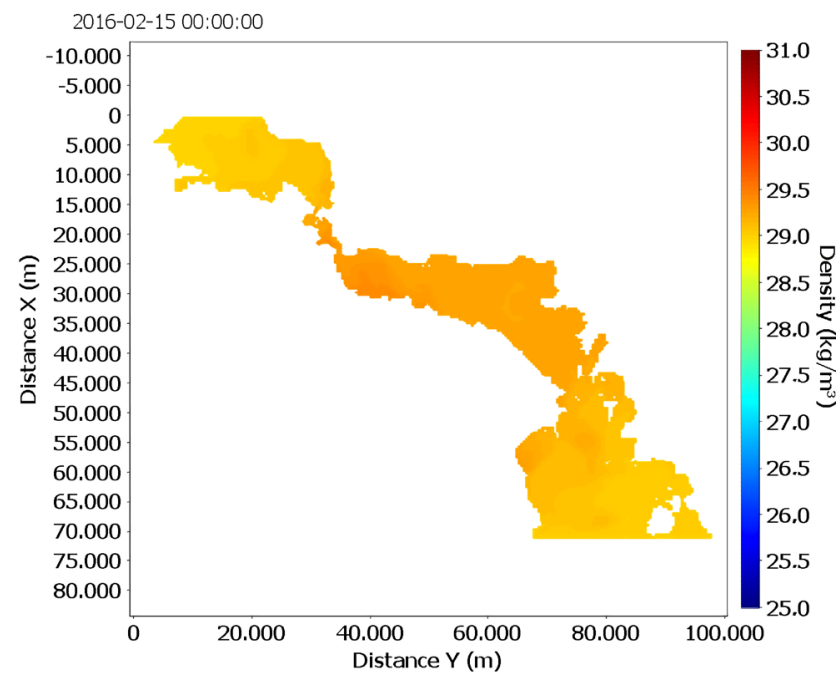

(a)

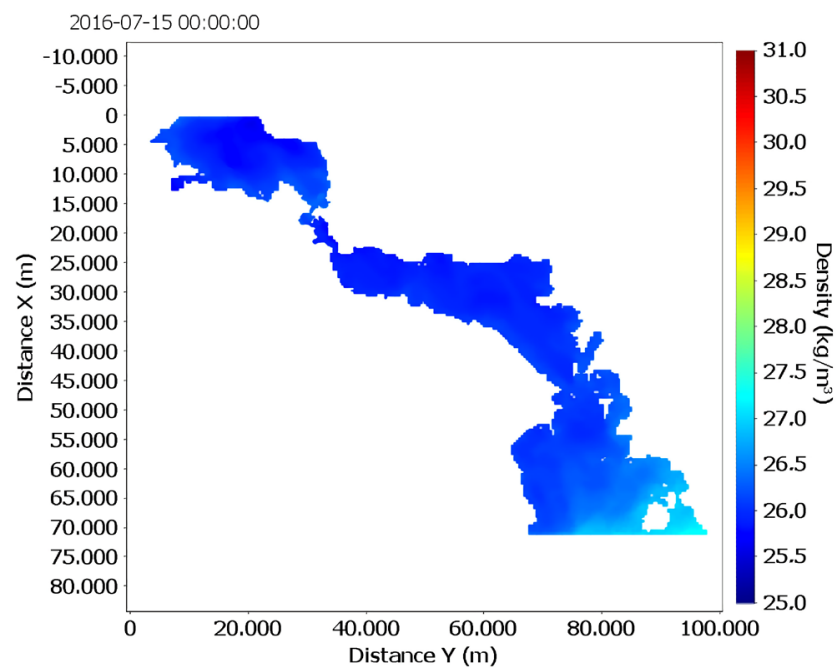

(c)

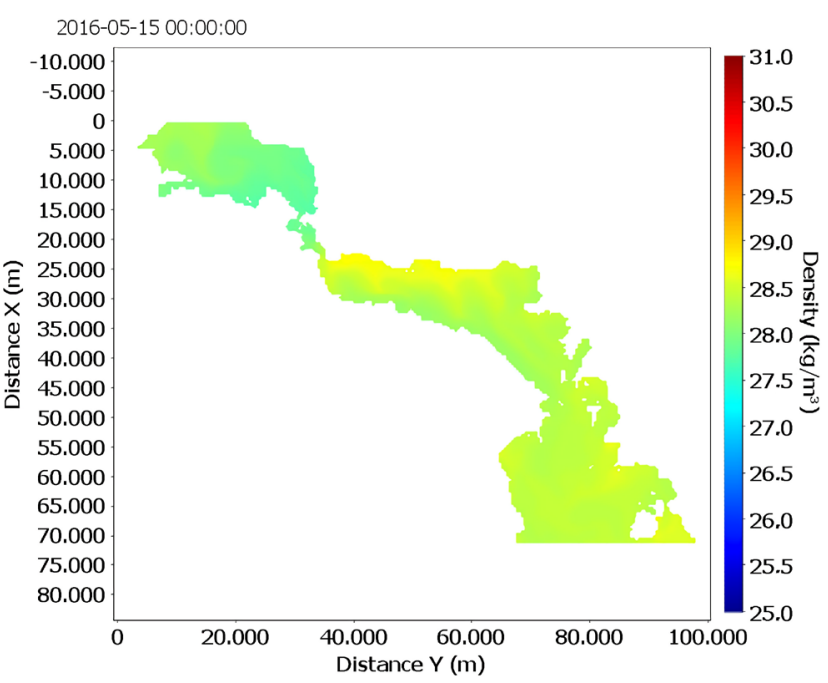

(b)

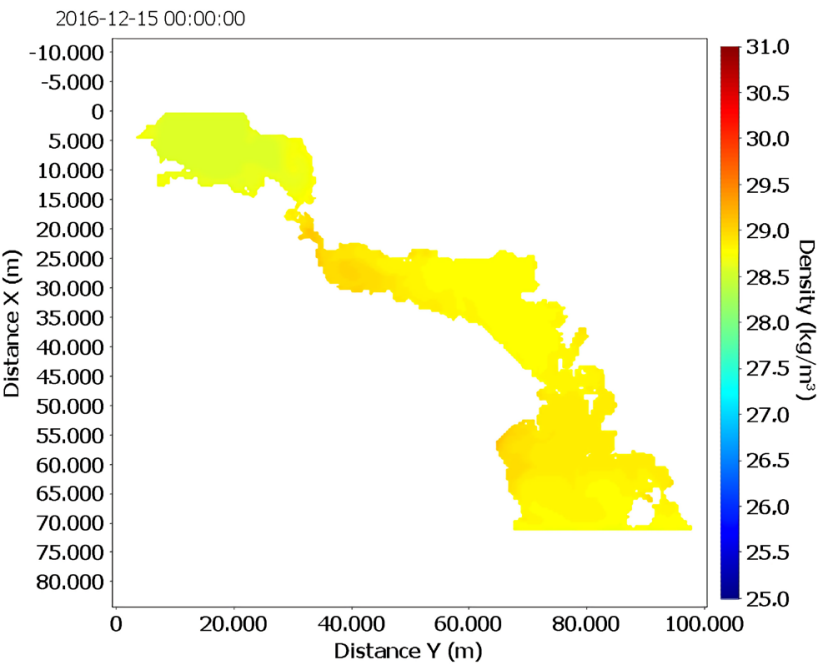

(d)

Figure 13. Density distribution in the surface layer of the Gulf of Evoikos, in the middle of the months of February (a), May (b), July (c), December (d), on the year 2016.

the Gulf of Evoikos, in the middle of the months of February, May, July, December, of the year 2016. The density $\sigma$ is connected to the density $\rho$ through the function $\rho=1000+\sigma\left(\mathrm{Kg} / \mathrm{m}^{3}\right)$. It appears that the density assumes smaller values in the months of July and May, due to an increased temperature, compared to February and December.

Figure 14 shows an indicative variation diagram of the water column depth regarding its density, temperature, and salinity, as obtained based on the simulation of the hydrodynamic ELCOM model, for point K1. This diagram refers to a specific time period (30-7-2016) of the summer season, when the temperature variation appears rather great moving deeper, as indicated in Figure 14(b). It is clearly observed that the distribution of water density (Figure 14(a)) in relation to the depth is mainly influenced by the corresponding temperature and less by the change in salinity values (Figure $14(\mathrm{c})$ ). The generated, approximately linear, 

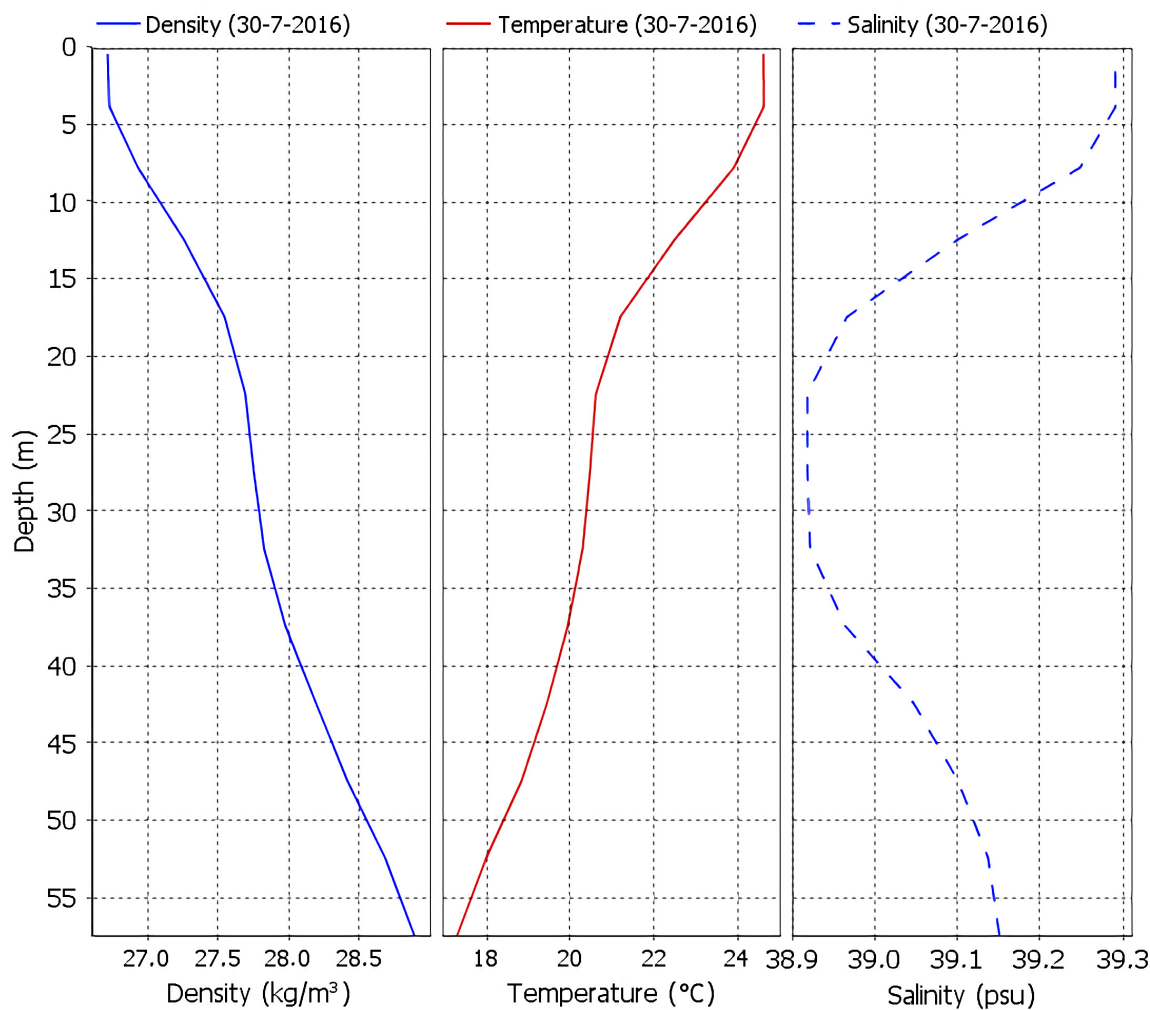

Figure 14. Indicative density (a), temperature (b), and salinity (c), distribution in relation to depth at point $\mathrm{K} 1$ at a specific time point (30-7-2016) of the summer season.

density stratification prevents the vertical mixing of marine water masses and, therefore, the mixing of their physiochemical parameters, such as nutrients and oxygen. However, it positively affects the entrapment of processed and chlorinated effluents discharged from underwater sewage sludges in greater depths, preventing them from reaching the free surface, thus allowing greater health safety for swimmers.

\subsection{Tracer Concentration}

An interesting question that arises based on this research is whether the South Aegean waters, which enter the southern Gulf of Evoikos through the southern "open" boundary condition, also pass through the Euripus Straits afterward, and spread to the northern Gulf of Evoikos or whether this is not the case due to the tide. Figure 15 illustrates the surface concentration of tracer-south for the months of April (a) and December (b). This indicator takes a value of 1.0 in the southern "open" boundary condition, along the whole depth. As can be observed from Figure 15, in April, there is a partial surface spread of the concentration in the southern Gulf of Evoikos, while in December it spreads completely superficially and marginally approaches the Euripus Straits, without, however, passing through them. In cases (c) and (d) of the same Figure, which demonstrate the diffusion of the tracer-south indicator throughout points of the computational space, corresponding to the midpoints of the water columns, the same phenomenon is 


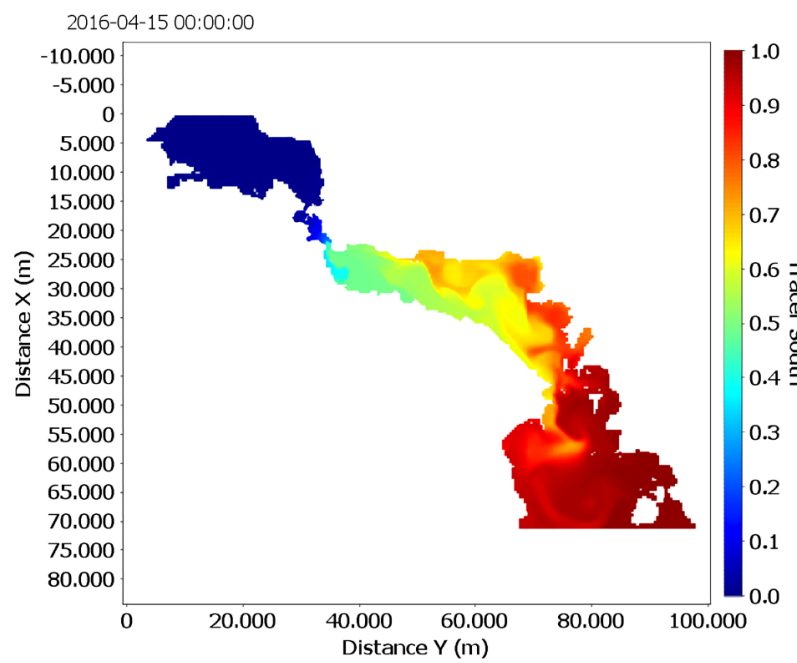

(a)

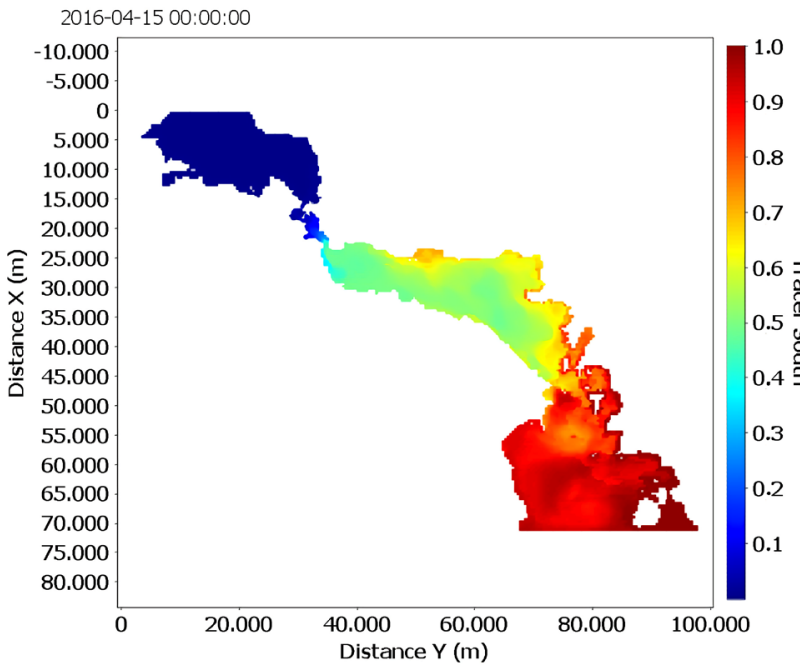

(c)

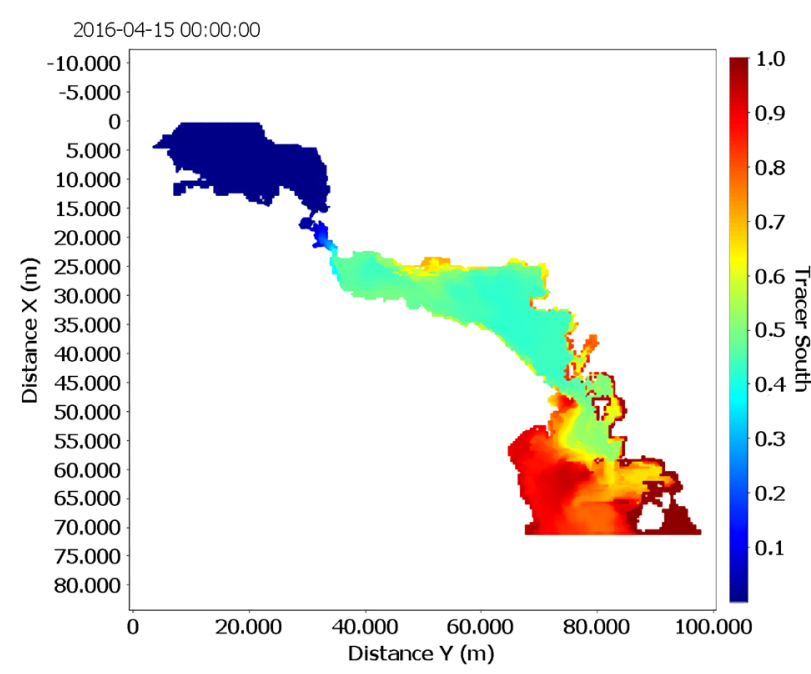

(e)

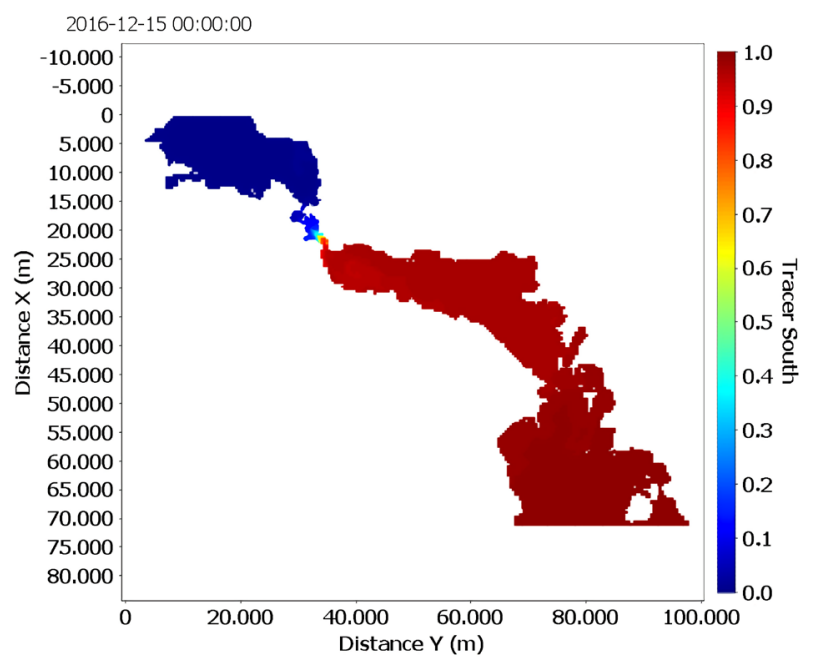

(b)

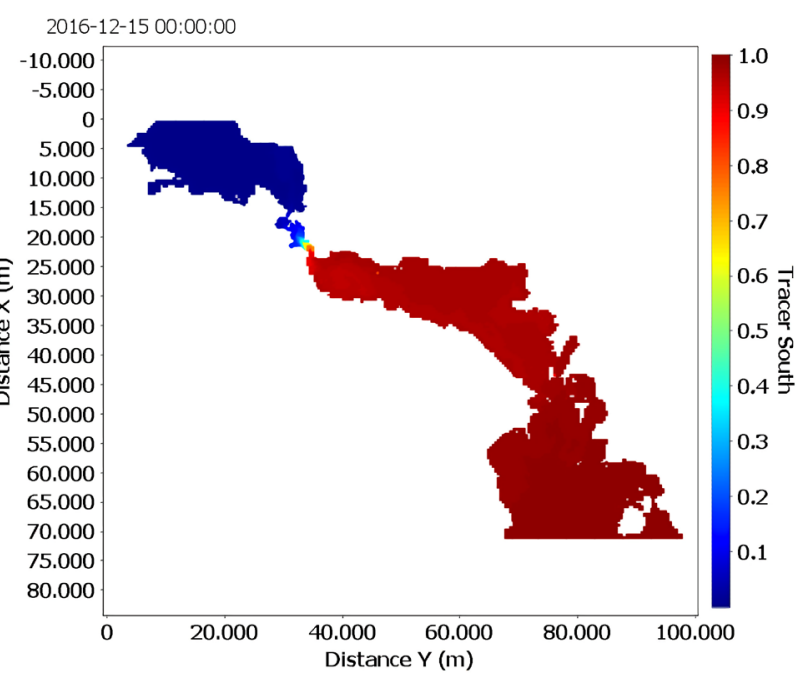

(d)

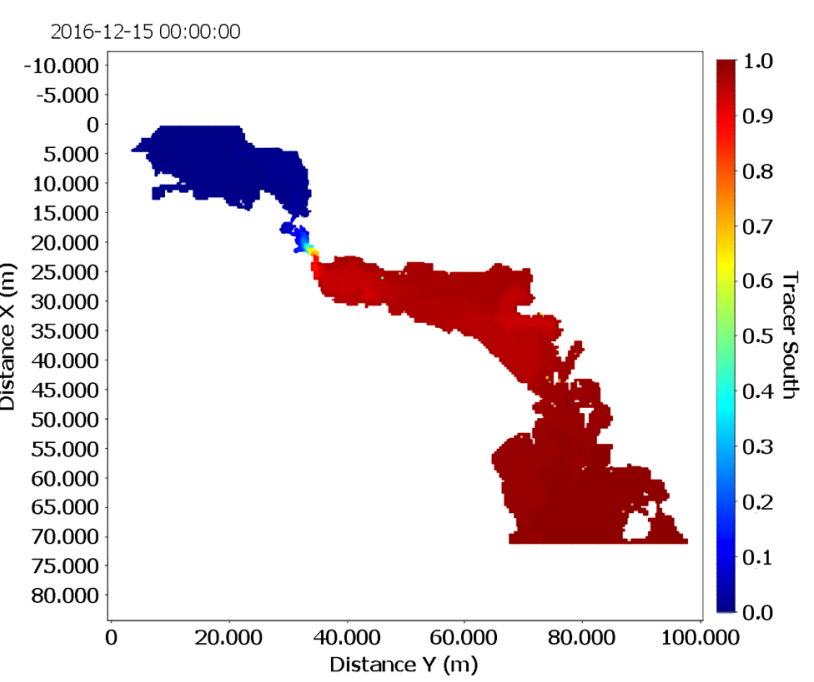

(f)

Figure 15. Concentration of the tracer-south during the months of April (a) and December (b) on the surface, on April (c) and December (d) in the midpoints of the water columns, and on April (e) and December ( $f$ ) at the sea bottom. 
observed, though to a lesser extent. This fact indicates that the inflow of the South Aegean waters is greater on the surface and decreases as the depth increases. This conclusion is also confirmed by Figure 15(e) and Figure 15(f), illustrating the diffusion of the tracer-south indicator at the sea bottom.

Figure 16(a) shows the variation of the concentration of tracer-south in relation to depth, at point K1, located in the southern Gulf of Evoikos (Figure 1), for several months. According to the results, initially, at the beginning of February, the concentration in the surface layers is 0.83 , while at the sea bottom it is 0.55 . The greater diffusion of the tracer-south on the surface layers is mainly due to the tide and the more intense velocity fields at the surface, and less due to the vertical mixing. This phenomenon continues during April as well, where the concentration of tracer-south exceeds the value of 0.9 , for a depth of up to $28 \mathrm{~m}$ from the surface, and progressively decreases as the depth increases, reaching a value of 0.55 . In mid-June, the tracer-south concentration value approaches 1.0 for depths from $12 \mathrm{~m}$ to $27 \mathrm{~m}$, while it reaches a slightly smaller value and equal to 0.91 on the surface layer, with a depth of $8 \mathrm{~m}$. After 10 months of simulation, in October the concentration value of tracer-south approaches 1.0 across the entire depth range of the water column, at point $\mathrm{K} 1$.

Figure 16(b) illustrates the variation in relation to depth for the tracer-south concentration value at point K3, located in the northern Gulf of Evoikos (Figure 1),

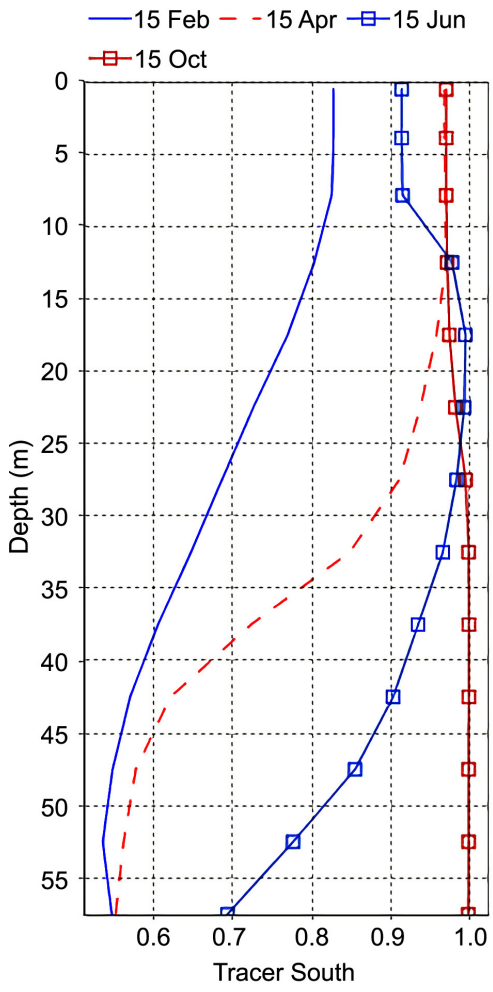

(a)

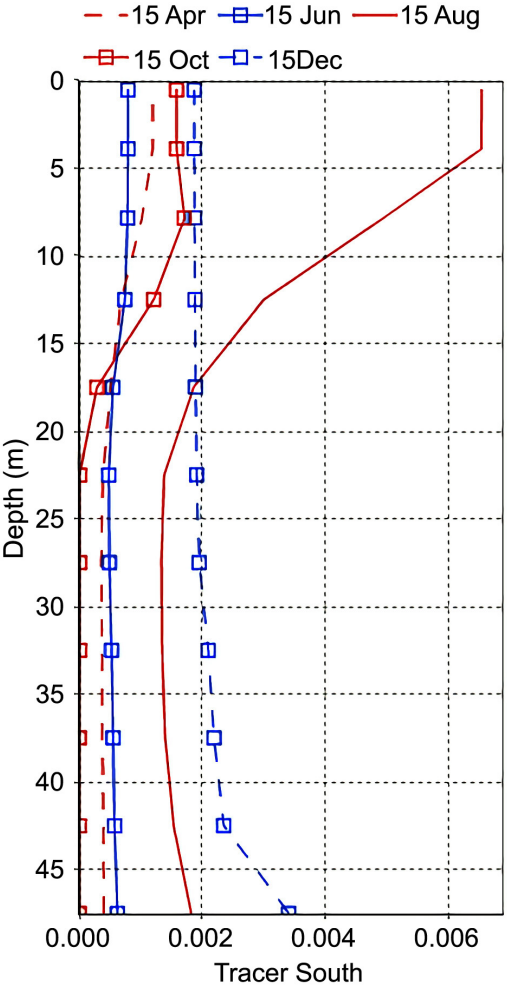

(b)

Figure 16. Concentration variation of tracer-south in relation to depth, at point K1 (a), for the southern Gulf of Evoikos, and at point K3 (b) for the northern Gulf of Evoikos, for several months. 
for several months. Based on this figure, we extract the minimum concentration values, specifically $0.002-0.006$, which, in general indicate a very small amount of diffusion of the South Aegean waters in the area of the northern Gulf of Evoikos. For all water column depths greater than $10 \mathrm{~m}$, we observe lower concentration values of the tracer-south in comparison to the surface layers, across all time periods. This is due to the fact that the communication between the northern and the southern Gulf of Evoikos takes place through the Euripus Straits, which present a shallow depth of nearly $10 \mathrm{~m}$, and consequently, the diffusion of the tracer-south to deeper levels of the northern Gulf of Evoikos is realized exclusively through the mechanism of vertical mixing. After 12 months of simulation, in December, the concentration value of tracer-south across the entire depth of the water column appears very small, approximately reaching 0.002 . On the surface layers, extending to depths of up to $10 \mathrm{~m}$, and at various times, a certain amount of variation is observed, due to hydrodynamic circulation, with insignificant, however, concentration values, that in no case exceed the value of 0.006. So, it is deduced from these results, that about 10 months are needed for the tracer-south concentration to approach a value of 1 , in the point $\mathrm{K} 1$ in the southern Evoikos region, across the entire depth of the water column. On the other hand, the concentration of this indicator is negligible in the northern Gulf of Evoikos, even after one year.

Figure 17(a), Figure 17(b) depict the variation of the tracer-south concentration value, in relation to depth at two points of the central Southern Evoikos,

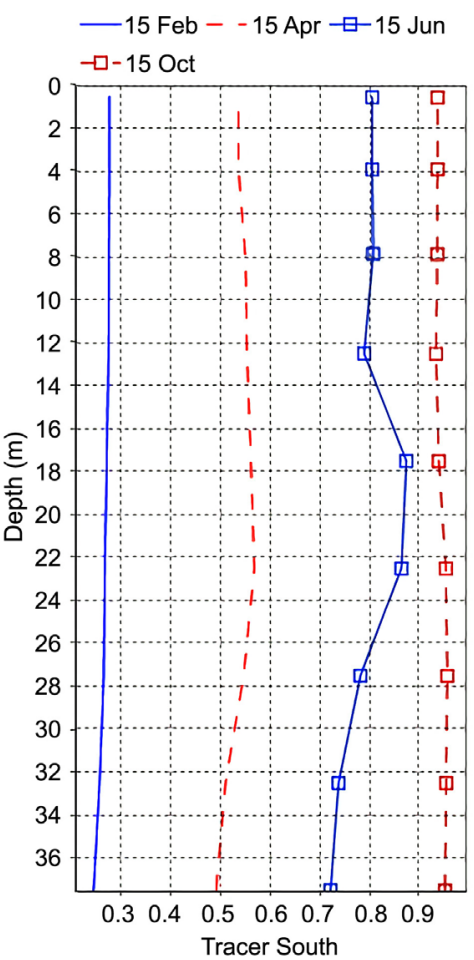

(a)

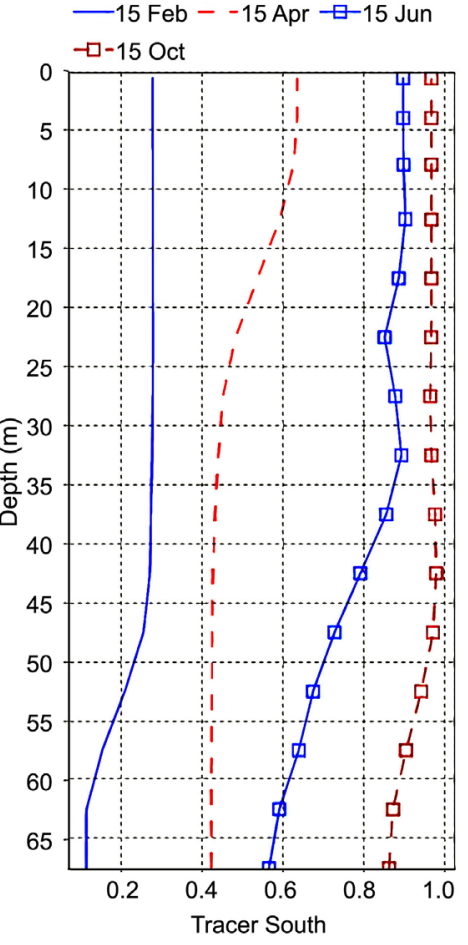

(b)

Figure 17. Concentration variation of tracer-south in relation to depth at points K4 (a) and K5 (b) of the southern Gulf of Evoikos for several months. 
specifically K4 and K5 (Figure 1). The distribution of the tracer-south concentration at point K5 (Figure 17(b)), located further north in relation to point K1, and at a depth of $10 \mathrm{~m}$, presents an illustration similar to that of point $\mathrm{K} 1$, but with some time lag. Thus, in February and April, the point K5 presents smaller concentrations of tracer-south in comparison to the point $\mathrm{K} 1$, while in June and October, they both show similar distributions and similar values.

Point K4 is located even further north in relation to point $\mathrm{K} 5$, and close enough to the Euripus Strait. Due to the smaller depth $(36.5 \mathrm{~m})$ in relation to the $\mathrm{K} 5$ and $\mathrm{K} 1$ points, $\mathrm{K} 4$ presents more uniform tracer-south concentration distributions over depth. These distributions observed at point K4 are approximately the same as those recorded on point $\mathrm{K} 5$ for depths up to $36.5 \mathrm{~m}$.

Based on the observations and data mentioned in detail above, it is concluded that the concentration of the tracer-south indicator approaches a value of 1 in the entire southern Evoikos region, both on the surface and in relation to the depth, after almost a 6-month time period. On the contrary, the concentration of this indicator is minimum in the northern Gulf of Evoikos.

\section{Conclusions}

For the purposes of this paper, we simulated the hydrodynamic circulation in the area of the Gulf of Evoikos using the ELCOM three-dimensional hydrodynamic model, including the effect of the tide, as well as atmospheric forcing. The validity of the present simulation is further confirmed by the predicted maximum velocity in the Euripus Straits, which is equal to the measured value in the field. Based on the analysis, we were able to derive the velocity field ranges, both on the surface and at various depths, for each point in time. It was found that the velocity distribution over depth, in the Euripus Strait, was approximately constant.

The predictions of this study for the mean salinity and the mean temperature were compared to those based on the COPERNICUS system, for all months of the annual simulation, at two points, specifically $\mathrm{K} 1$ and $\mathrm{K} 2$ and for different depths, and were considered satisfactory. The temporal evolution of the mean salinity values, at the points $\mathrm{K} 1$ and $\mathrm{K} 2$, seems to be similar to the southern open boundary input salinity, but with a time lag. At the same points $\mathrm{K} 1$ and $\mathrm{K} 2$, the mean water temperature is usually slightly greater at the water surface than the one at the depth of $10 \mathrm{~m}$, almost for all months. Also, the distribution of the mean temperature at the point K1, and for the months of May and June, is almost linear over the depth.

Furthermore, it was observed that the distribution of water density in relation to depth is mainly influenced by the change in temperature and less by the change in salinity. During various time periods (mainly during the warmer months) an almost linear density stratification is created in relation to the depth, which prevents the vertical mixing of marine masses and, consequently, the mixing of their physicochemical parameters, such as their nutrients and oxygen. 
The penetrative convection, the wind stress and the tide are strong driving forces of the movement and mixing of the water masses of the study area. However, they are not able to destroy the density stratification in these not very deep coastal waters. This is an important finding of the present work, because it is very crucial for the dilution of the wastewater disposed from existing five diffusers.

Moreover, a broad diffusion of a hypothetical tracer-south, originating from the South Aegean Sea and spreading to the southern Evoikos, was also noted, which, in time, over a 6-month period, had virtually spread across the depth of the southern Gulf of Evoikos. This is a very important finding, because if the hypothetical tracer-south is for example clear water entering from the Aegean Sea (north boundary condition), about six months are needed to replace almost all the maybe polluted water of the southern Gulf of Evoikos. On the contrary, the diffusion of this indicator in the region of the northern Gulf of Evoikos appeared infinitesimal, due to the tide, as well as the limited communication between the northern and southern Gulf of Evoikos. This is also an important finding of the present work, because pollutants from the southern Gulf of Evoikos are not transferred to the northern Gulf.

In this study, we investigated and assessed the physical and hydrodynamic characteristics of this tidal flow, such as the salinity, the water temperature, the density stratification, the water circulation, the flow rates, etc. Apart from the contribution of this work to the understanding of this complex flow, many useful conclusions have emerged and a cohesive basis was set for the further environmental simulation of the diffusion and dispersion of passive pollutants in this area, under the intense effect of the tidal loading, as well as bathymetry.

\section{Conflicts of Interest}

The authors declare no conflicts of interest regarding the publication of this paper.

\section{References}

[1] Pirooznia, M., Emadi, S.R. and Alamdari, M.N. (2016) The Time Series Spectral Analysis of Satellite Altimetry and Coastal Tide Gauges and Tide Modeling in the Coast of Caspian Sea. Open Journal of Marine Science, 6, 258-269. https://doi.org/10.4236/ojms.2016.62021

[2] Onguene, R., et al. (2015) Overview of Tide Characteristics in Cameroon Coastal Areas Using Recent Observations. Open Journal of Marine Science, 5, 81-98. https://doi.org/10.4236/ojms.2015.51008

[3] Manasrah, R. (2013) Tide Variation and Signals during 2000-2004 in the Northern Gulf of Aqaba, Red Sea. Natural Science, 5, 1264-1271. https://doi.org/10.4236/ns.2013.512154

[4] Pous, S., Carton, X. and Lazure, P. (2012) A Process Study of the Tidal Circulation in the Persian Gulf. Open Journal of Marine Science, 2, 131-140. https://doi.org/10.4236/ojms.2012.24016

[5] Vanlede, J., Coen, L. and Deschamps, M. (2014) Tidal Prediction in the Sea Scheldt 
(Belgium) Using a Combination of Harmonic Tidal Prediction and 1D Hydraulic Modeling. Natural Resources, 5, 627-633. https://doi.org/10.4236/nr.2014.511055

[6] Livieratos, E. (1980) The $\mathrm{M}_{2}$ Sea-Tidal Propagation in the Evoikos Bay. Technika Chronika, 5, 48-55.

[7] Eginitis, D. (1929) The Problem of the Tides of Euripus. Astronomische Nachrichten, 236, 321.

[8] Endros, A. (1915) Die Gezeiten, Seiches und Stromungen des Meeresbei Aristoteles. Sitzungsberichte der Bayerischen Akademie der Wissenschafter (math.-phys.), Kl, 99.

[9] Sterneck, R.V. (1916) Zur Theorie der Euripus-Stromungen. Sitzungsberichte der Akademie der Wissenschafter in Wien (Abt. IIa).

[10] Defant, A. (1961) Physical Oceanography Volume II. Pergamon Press, London.

[11] Tsimplis, M.N. (1997) Tides and Sea-Level Variability at the Strait of Euripus. Estuarine, Coastal and Shelf Science, 44, 91-101. https://doi.org/10.1006/ecss.1996.0128

[12] Wöppelmann, G. and Marcos, M. (2012) Coastal Sea Level Rise in Southern Europe and the Non-Climate Contribution of Vertical Land Motion. Journal of Geophysical Research, 117, C01007. https://doi.org/10.1029/2011JC007469

[13] Ferrarin, C., Bellafiore, D., Sannino, G., Bajo, M. and Umgiesser, G. (2018) Tidal Dynamics in the Inter-Connected Mediterranean, Marmara, Black and Azov Seas. Progress in Oceanography, 161, 102-115. https://doi.org/10.1016/j.pocean.2018.02.006

[14] Poulos, S., Drakopoulos, P., Leontaris, S., Tsapakis, E. and Hatjiyianni, E. (2001) The Contribution of Tidal Currents in the Sedimentation of Strait of Avlida, Southern Evoikos Gulf, Greece. Proceedings of the 9th International Congress, Athens, 26-28 September 2001, 731-736.

[15] Tsimplis, M.N. and Shaw, G.P. (2010) Seasonal Sea Level Extremes in the Mediterranean Sea and at the Atlantic European Coasts. Natural Hazards and Earth System Sciences, 10, 1457-1475. https://doi.org/10.5194/nhess-10-1457-2010

[16] Marcos, M., Tsimplis, M.N. and Shaw, A.G.P. (2009) Sea Level Extremes in Southern Europe. Journal of Geophysical Research, 114, C01007. https://doi.org/10.1029/2008JC004912

[17] Fourniotis, N.T., Horsch, G.M. and Leftheriotis, G.A. (2018) On the Hydrodynamic Geometry of Flow-Through versus Restricted Lagoons. Water (Switzerland), 10, 237. https://doi.org/10.3390/w10030237

[18] Kontoyiannis, H., Panagiotopoulos, M. and Soukissian, T. (2015) The Euripus Tidal Stream at Halkida/Greece: A Practical, Inexpensive Approach in Assessing the Hydrokinetic Renewable Energy from Field Measurements in a Tidal Channel. Journal of Ocean Engineering and Marine Energy, 1, 325-335. https://doi.org/10.1007/s40722-015-0020-8

[19] Kopasakis, K.I., Georgoulas, A.N., Angelidis, P.B. and Kotsovinos, N.E. (2012) Simulation of the Long-Term Fate of Water and Pollutants, Transported from the Dardanelles Plume into the North Aegean Sea. Applied Ocean Research, 37, 145-161. https://doi.org/10.1016/j.apor.2012.04.007

[20] Kopasakis, K., Georgoulas, A., Angelidis, P. and Kotsovinos, N. (2012) Numerical Modeling of the Long-Term Transport, Dispersion and Accumulation of Black Sea Pollutants into the North Aegean Coastal Waters. Estuaries and Coasts, 35, 1530-1550. https://doi.org/10.1007/s12237-012-9540-9

[21] Spillman, C.M., Imberger, J., Hamilton, D.P., Hipsey, M.R. and Romero, J.R. (2007) 
Modeling the Effects of Po River Discharge, Internal Nutrient Cycling and Hydrodynamics on Biogeochemistry of the Northern Adriatic Sea. Journal of Marine Systems, 68, 167-200. https://doi.org/10.1016/j.jmarsys.2006.11.006

[22] Alosairi, Y., Imberger, J. and Falconer, R.A. (2011) Mixing and Flushing in the Persian Gulf (Arabian Gulf). Journal of Geophysical Research: Oceans, 116. https://doi.org/10.1029/2010JC006769

[23] Kapsimalis, V., Panagiotopoulos, I.P., Hatzianestis, I., Kanellopoulos, T.D., Tsangaris, C., Kaberi, E., Kontoyiannis, H., Rousakis, G., Kyriakidou, C. and Hatiris, G.A. (2013) A Screening Procedure for Selecting the Most Suitable Dredged Material Placement Site at the Sea. The Case of the South Euboean Gulf, Greece. Environmental Monitoring and Assessment, 185, 10049-10072. https://doi.org/10.1007/s10661-013-3312-2

[24] Hodges, B. and Dallimore, C. (2010) ELCOM User Manual. CWR, University of Western Australia, Crawley.

[25] Hodges, B. and Dallimore, C. (2010) ELCOM Science Manual. CWR, University of Western Australia, Crawley.

[26] Pinardi, N., Allen, I., Demirov, E., De Mey, P., Korres, G., Lascaratos, A., Le Traon, P.-Y., Maillard, C., Manzella, G. and Tziavos, C. (2003) The Mediterranean Ocean Forecasting System: First Phase of Implementation (1998-2001). Annales Geophysicae, 21, 3-20. https://doi.org/10.5194/angeo-21-3-2003

[27] Pinardi, N. and Coppini, G. (2010) Operational Oceanography in the Mediterranean Sea: The Second Stage of Development. Ocean Science, 6, 263-267. https://doi.org/10.5194/os-6-263-2010

[28] Tonani, M., Teruzzi, A., Korres, G., Pinardi, N., Crise, A., Adani, M., Oddo, P., Dobricic, S., Fratianni, C., Drudi, M., Salon, S., Grandi, A., Girardi, G., Lyubartsev, V. and Marino, S. (2011) The Mediterranean Monitoring and Forecasting Centre, a Component of the MyOceanSystem. Proceedings of the 6 th International Conference on EuroGOOS, Sopot, 4-6 October 2011, 131-135.

[29] Kotsovinos, N. (1987) The Problem of Pollution in the Gulf of Evoikos. In: Proceedings of the International Scientific Conference "The City of Chalkida", Company of Euboean Studies, Chalkida, 353-387.

[30] Skaloumpakas, K. (2011) Study of the Tidal Energy Potential at the Euripus Strait and Operating Modes through Tidal Turbine Installation. Degree Thesis, National Technical University of Athens, Athens. 